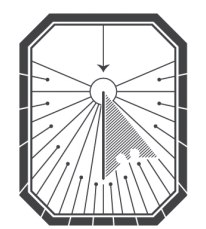

KYIV-MOHYLA

LAW \& POLITICS JOURNAL

KYIV-MOHYLA SCHOLARLY PEER-REVIEWED JOURNALS

The Winter of Our Discontent: Emotions and

Contentious Politics in Ukraine during Euromaidan

Author: Ivan Gomza, Nadiia Koval

Source: Kyiv-Mohyla Law and Politics Journal 1 (2015): 39-62

Published by: National University of Kyiv-Mohyla Academy

http://kmlpj.ukma.edu.ua/ 


\title{
The Winter of Our Discontent: Emotions and Contentious Politics in Ukraine during Euromaidan
}

\author{
Ivan Gomza \\ National University of Kyiv-Mohyla Academy, \\ Department of Political Science
}

\section{Nadiia Koval}

National Institute for Strategic Studies

\begin{abstract}
Drawing upon 6o semi-structured interviews, this study adopts an emotion-centered approach to studying the non-violent phase of Euromaidan protests in Ukraine. We find that, first, the overlapping and mutual amplifying of two successive moral shocks was the primary mechanism of mobilization. The mobilizing success of the moral shocks is interpreted through introducing the notion of emotional path dependence. Second, the nature of moral shock is explained as a combination of emotional and cognitive components. Third, we find that emotional components of collective identity construction created moral barriers between a brotherhood of virtuous protesters and profoundly immoral antagonists, which, combined with the perceived universality of claims, rendered the bystanders' position unacceptable.
\end{abstract}

Key Words: social movements, moral shock, Euromaidan, mobilization, collective identity, emotions.

\section{唡}

At the end of 2013 Ukraine experienced an eruption of contentious politics known under the brand of Euromaidan. The latter was profoundly imbued with and driven by emotions: people inspiringly sang the national anthem on Independence Square, ferociously stormed the presidential residence with a bulldozer, resolutely occupied governmental building, triumphantly knocked over Lenin's monuments and hurriedly sought sanctuary in a medieval cathedral after merciless acts of police brutality. We are interested in exploring what role emotions played in mobilizing thousands of people to the streets and in keeping them there for months. Our focus is consistent not only with the emotionalized course of protest events, but also with the theoretical agenda of "bringing the emotions back in" in studying the contentious politics. ${ }^{1}$

See for instance Jeff Goodwin, James M. Jasper and Francesca Polletta, "The Return of the Repressed: The Fall and Rise of Emotions in Social Movement Theory," Mobilization 5.1 (200o): 65-83; Deborah Gould, "Passionate Political Processes: Bringing Emotions Back into the Study of Social Movements," in Rethinking Social Movements, ed. Jeff Goodwin and James M. Jasper (Lanham, MD: Rowman and 
This article begins by exploring the theoretical foundations of studying the role of emotions in contentious politics, with special attention given to the notion of moral shock. Second, we study two moral shocks that brought to life the Euromaidan protests and introduce the idea of emotional path dependency. Third, we consider the role of emotions in sustaining the protest and creating the emotional community of the protesters by exploring their attitude to the antagonists, bystanders and companions.

\section{Theoretical Context}

The very first attempt to understand the nature of contentious politics, the collective behavior paradigm, ${ }^{2}$ overloaded as it was with an emphasis upon emotions, was primitive, irrational, and chaotic. A backflow in the theory of contentious politics, i.e., the resource mobilization paradigm, ${ }^{3}$ considered contentious politics as well-planned activities seeking to achieve collective goods. Although theoretically opposed to the collective behavior tradition, the resource mobilization theory ignored emotions as irrational and incompatible with effective resource mobilization.

In the late 1980s, the drift of movement culture studies and collective identity studies to the focus of social movements' research ${ }^{4}$ opened the way to recognizing emotions as components of social movement culture. ${ }^{5}$ Exploring the foundations of collective identity, Melucci emphasized that it consists of cognizing process, social networks and "emotional investment, which enables

Littlefield, 2003), 155-75; Mustafa Emirbayer and Chad A. Goldberg, "Pragmatism, Bourdieu, and Collective Emotions in Contentious Politics" Theory and Society 34 (2005): 469-518.

See Gustave Le Bon, Psychologie des foules (Paris: Édition Félix Alcan, 1905); Eric Hoffer, The True Believer (New York: Frederic A. Praeger, 1962); Herbert Blumer, “Collective Behavior," in Principles of Sociology, ed. Alfred McClung Lee (New York: Barnes and Noble, 1969), 65-121.

3 See Anthony Oberschall, Social Conflict and Social Movements (Englewood Cliffs, NJ: Prentice Hall, 1973); William A Gamson, The Strategy of Social Protest (Homewood, IL: Dorsey Press, 1975); John D. McCarthy and Mayer N. Zald, "Resource Mobilization and Social Movements: A Partial Theory," American Journal of Sociology 82.6 (1977): 1212-41.

4 See Alain Touraine, La Voix et le Regard (Paris: Éditions du Seuil, 1978); Jean Cohen, "Strategy or Identity: New Theoretical Paradigms and Contemporary Social Movements," Social Research 52.4 (1985): 663-716; Doug McAdam, "Culture and Social Movements," in New Social Movements: From Ideology to Identity, ed. Enrique Laraña, Hank Johnston and Joseph R. Gusfield (Philadelphia: Temple University Press, 1994), 36-57; Myra Marx Ferree and Frederick D. Miller, "Mobilization and Meaning: Toward an Integration of Social Psychological and Resource Mobilization Perspectives on Social Movements," Sociological Inquiry 55.1 (1985): 38-51.

See for instance John Lofland, “Charting Degrees of Movement Culture: Tasks of the Cultural Cartographer," in Social Movements and Culture, ed. Hank Johnston and Bert Klandermans (Minneapolis: University of Minnesota Press, 1995), 188-216; Suzanne Staggenborg, “The 'Meso' in Social Movement Research," in Social Movements: Identity, Culture, and the State, ed. David S. Meyer, Nancy Whittier, and Belinda Robnett (New York: Oxford University Press, 2002), 124-40. 
individuals to feel like part of a common unity." ${ }^{2}$ Many scholars followed Melucci, binding emotions to the process of collective identity formation. ${ }^{7}$ Thus, cultural identity approaches have opened the door for the full-scale studying of emotions in social movements and after "twenty years of theory and research," 8 the discipline has produced valuable theoretic accomplishments.

Firstly, scholars rejected the idea of a dichotomy between rational cognition and emotional reaction. Gamson emphasizes that cognizing process is laden with emotion..$^{9}$ Jasper argued in a number of publications that understanding emotions as purely irrational and unpredictable reactions was erroneous. ${ }^{10}$ He distinguished five types of emotions: urges, reflexes, affects, moods, and moral emotions. The latter, he supposed, being the most complex, socially embedded, and tightly connected with cognizing process are the most important for collective action. ${ }^{11}$ According to Jasper's conclusions, rational and irrational components are equally mixed within the triad of cognition, emotion, and morality. ${ }^{12}$ As he and his collaborators put it, "by defining rationality in contrast to — and as incompatible with — emotionality, resource mobilization and political process theorists missed powerful springs of collective action."13 That itinerary was followed by other scholars who started incorporating emotional elements into their studies. ${ }^{14}$ Still, the interaction between emotions and cognition during mobilization requires further conceptualization.

6 Alberto Melucci, “The Process of Collective Identity in Social Movements and Culture," in Social Movements and Culture, ed. Hank Johnston and Bert Klandermans (Minneapolis: University of Minnesota Press, 1995), 44-45.

7 See for instance David A. Snow and Doug McAdam, "Identity Work Processes in the Context of Social Movements: Clarifying the Identity/Movement Nexus," in Self, Identity and Social Movements, ed. Sheldon Stryker, Timothy J. Owens, and Robert W. White (Minneapolis: University of Minnesota Press, 2000), 41-67; Jacqueline Adams, “The Bitter End: Emotions at a Movement's Conclusion,” Sociological Inquiry 73.1 (2003): 84-113; Lorraine Bayard de Volo, "The Dynamics of Emotion and Activism: Grief, Gender, and Collective Identity in Revolutionary Nicaragua," Mobilization 11.4 (2006): 461-74.

8 James M. Jasper, “Emotions and Social Movements: Twenty Years of Theory and Research," Annual Review of Sociology 37 (2011): 285-303.

9 William A. Gamson, "Constructing Social Protest," in Social Movements and Culture, ed. Hank Johnston and Bert Klandermans (Minneapolis: University of Minnesota Press, 1995), 85-106.

10 James M. Jasper, The Art of Moral Protest: Culture, Biography, and Creativity in Social Movements (Chicago: University of Chicago Press, 1997); James M. Jasper, "The Emotions of Protest: Affective and Reactive Emotions in and around Social Movements," Sociological Forum 13.3 (1998): 397-424; James M. Jasper, "Cultural Approaches in the Sociology of Social Movements," in Handbook of Social Movements across Disciplines, ed. Bert Klandermans and Conny Roggeband (New York: Springer, 2007), 59-110.

11 James M. Jasper, "Motivation and Emotion," in Oxford Handbook of Contextual Political Analysis, ed. Robert Goodin and Charles Tilly (New York; Oxford: Oxford University Press, 2006), 157-72.

12 Jasper, "Cultural Approaches," 81.

13 Goodwin et al., "The Return of the Repressed," 71.

14 See, for instance, Ron Aminzade and Doug McAdam, "Emotions and Contentious Politics," in Silence and Voice in the Study of Contentious Politics, ed. Ron Aminzade et al. (Cambridge: Cambridge 
Secondly, the reconsideration of emotions in social movements contributed to a more realistic understanding of mobilization mechanisms. Prior to the re-incorporation of emotions into the scholars' research kit, the mobilization was predominantly considered a networkeffect. ${ }^{15}$ However, a theoretical problem arose: how can movements gain support of people not incorporated into social movement networks? In order to resolve the problem, the notion of "moral shock" was introduced, with moral shock being understood as "an unexpected event or piece of information [which] raises such a sense of outrage in a person that she becomes inclined toward political action., ${ }^{16}$ Yang used a similar concept of a critical emotional event, ${ }^{17}$ although the denomination "moral shock" prevails in the scholarly literature. A person being exposed to some revolting materials like pictures of tortured animals ${ }^{18}$ or violations of fundamental international laws ${ }^{19}$ is inclined to the spontaneous creation of emotional bounds with the affected subject and may experience vivid emotions like shame or anger that are significantly important for mobilization. ${ }^{20}$ Hence, mobilization through moral shock is not a consequence of network-inclusion but an effect of emotional dynamics.

Moral shocks are basic components of radicalization because sympathetic, yet rather passive, individuals do mobilize after traumatizing events and violent emotions, especially in cases of political extremism: "Chechen Black Widows are described as seeking revenge against Russians for their own experience of rape or for the deaths of their menfolk. Tamil Tigers of the suicide brigades [...] are often described as survivors of Sinhalese atrocities." ${ }^{21}$ This model of radicalization implies that the person had already possessed some characteristics,

University Press, 2001), 14-5o; Sidney G. Tarrow, Power in Movement (Cambridge: Cambridge University Press, 2011).

15 Aldon Morris, The Origins of the Civil Rights Movement (New York: Free Press, 1984); Robert V. Gould, "Multiple Networks and Mobilization in the Paris Commune," American Sociological Review 56.6 (1991): 716-29; Doug McAdam, and Ronnelle Paulsen, "Specifying the Relationship between Social Ties and Activism," American Journal of Sociology 99.3 (1993): 640-67.

16 Jasper, "The Emotions of Protest," 409.

17 Guobin Yang, "Emotional Events and the Transformation of Collective Action," in Emotions and Social Movements, ed. Helena Flam and Debra King (Abingdon: Routledge, 2005), 80.

18 James M. Jasper and Jane Poulsen, "Recruiting Strangers and Friends: Moral Shocks and Social Networks in Animal Rights and Anti-Nuclear Protests," Social Problems 42.4 (1995): 493-512.

19 Sharon Erickson Nepstad and Christian S. Smith, "The Social Structure of Moral Outrage in Recruitment to the U. S. Central America Peace Movement," in Passionate Politics: Emotions and Social Movements, ed. Jeff Goodwin, James M. Jasper, and Francesca Polletta (Chicago: University of Chicago Press, 2001), 158-74.

Hyojoung Kim, "Shame, Anger, and Love in Collective Action: Emotional Consequences of Suicide Protest in South Korea, 1991," Mobilization 7.2 (2002): 159-76; Martijn Van Zomeren, Russell Spears, Agneta H. Fischer, and Collin W. Leach, "Put Your Money Where Your Mouth Is! Explaining Collective Action Tendencies through Group-based Anger and Group Efficacy," Journal of Personality and Social Psychology 87.5 (2004): 649-64.

21 Clark McCauley and Sophia Moskalenko, "Mechanisms of Political Radicalization: Pathways toward Terrorism," Terrorism and Political Violence 20.3 (2008): 418. 
being more sensitive to particular stimuli, more disposed to emotional reaction, and, therefore, more prone to consequent choices. This means that moral shocks are not "suddenly imposed grievances"22: they turn out to be (at least partially) mediated and constructed by preexisting principles, beliefs, and affective loyalties. Thus, emotional responses and collective action built upon them are contextually dependent variables.

The nature of this context, however, remains questionable. The hard-line structural approach claims that "individual or collective actors engage in social, i.e., power and status, relations with other actors, and one result of those interactions is emotion - in both actors." ${ }^{23}$ On the other hand, the context of emotional responses may be interpreted through the phenomenological tradition as predefined by a hierarchy of values particular to the actor. Nepstad and Smith introduced the notion of cognitive accessibility, implying that "the cultural and social values connected to a group identity may infuse this information with a sense of urgency and a compelling need to respond." ${ }^{24}$ Either structurally or phenomenologically, a moral shock's context tends to be a central element of the mobilization through emotions and requires closer attention.

Thirdly, bringing emotions back in has contributed to a better understanding of social movement dynamics. Overtly put by Eyerman, "the force of emotion is an essential part of what keeps a movement moving and its lack helps explain its decline." 25 Without "emotional energy" ${ }^{\prime 26}$ the movement is unable to mobilize people and inspire them to face the adversary with determination. Sometimes participants get bored and quit the movement, ${ }^{27}$ sometimes they are too disillusioned and depressed to participate further, ${ }^{28}$ and sometimes they are unable to overcome limitations of "libidinal opportunity structure."29 On the other hand, properly used emotions help to surmount the free-rider problem and bring satisfaction with collective action and belonging to something bigger than an individual self. ${ }^{30}$

Edward J. Walsh, "Resource Mobilization and Citizen Protest in Communities around Three Mile Island," Social Problems 29.1 (1981): 121.

23 Theodore D. Kemper, "A Structural Approach to Social Movement Emotions," in Passionate Politics: Emotions and Social Movements, ed. Jeff Goodwin, James M. Jasper, and Francesca Polletta (Chicago, Ill.: University of Chicago Press, 2001), 62.

24 Nepstad and Smith, "The Social Structure," 166.

25 Ron Eyerman, "How Social Movements Move: Emotions and Social Movements," in Emotions and Social Movements, ed. Helena Flam and Debra King (Abingdon: Routledge, 2005), 43.

26 Randall Collins, "Social Movements and the Focus of Emotional Attention," in Passionate Politics: Emotions and Social Movements, ed. Jeff Goodwin, James M. Jasper, and Francesca Polletta (Chicago, Ill.: University of Chicago Press, 2001), 29. Aristide R. Zolberg, "Moments of Madness," Politics and Society 2 (1972): 183-207.

28 Sidney G. Tarrow, "Old Movements in New Cycles of Protest: The Career of an Italian Religious Community," International Social Movement Research 1 (1988): 281-304.

29 Jeff Goodwin, "The Libidinal Constitution of a High-Risk Social Movement: Affectual Ties and Solidarity in the Huk Rebellion, 1946 to 1954," American Sociological Review 62.1 (1997): 53-69. 
Animated by emotions, social movements are also machines for producing new emotions. Given that any social conflict comprehends three parties (a movement, its antagonist and bystanders), generated emotions can also be differentiated. Participants may feel love to one another, revulsion towards the antagonists and the whole range of emotion towards bystanders. Flam concedes that positive emotions are shared within the collectivity, while negative emotions are directed towards the antagonist. ${ }^{31}$ The question, however, remains: in which ways do positive emotions shared by participants and negative emotions projected outside contribute to movement progress and decline?

Studies of emotions in social movements have taken a substantial step forward in the last twenty years. Still, three focal points requiring further investigations include: (1) the interaction of emotional and cognitive elements in contentious politics; $(2)$ the contextuality of moral shocks; and (3) the role of emotional exchanges in movement dynamics. In following discussion, we explore all three focal points by examining contentious politics in Ukraine from November 2013 through part of January 2014.

\section{Methods}

We found qualitative methods as the most appropriate because our goal - to examine the role of emotions in contentious actions - was exploratory. The primary data collection method was 60 semi-structured personal interviews with protest participants, gathered and taperecorded in the Independence Square and its surroundings.

We interviewed both permanent residents of the protest camp and citizens participating during weekend mass-rallies. We did not detect significant differences in the emotions of the two groups. We randomly sampled the respondents, intentionally trying to question groups representing different sexes, ages, and social backgrounds.

We interviewed in Ukrainian or Russian, depending on interviewee's first choice. The questions were open-ended as we aimed to explore the participants' motives and attitudes. While we used an interview guide during each interview, we tried to build rapport with each respondent. Thus, our interviews were conversational. As a result, the questions' wording and ordering sometimes differed. We included several probes to guide respondents to desirable topics when they deviated from these topics.

Thus, virtually all respondents answered about the reasons for their participation; the emotional content of the mobilization; and their feelings towards their companions, the government, law enforcement agencies, and bystanders. The semi-structured interviews permitted us to observe the non-verbal indicators (emotional reactions and their range) that we considered useful for the study. We documented these indicators as field notes.

We began collecting data on 21 November 2013 and ended on 16 January 2014. After 16 January, the protest entered a more violent phase, resulting in considerable changes in emotional and cognitive perspectives, which require a separate study. Within this period,

James M. Jasper, and Francesca Polletta (Chicago, Ill.: University of Chicago Press, 2001), 272-73. 
we regularly tracked the observable emotional dynamics and the protest's emotional wave. In addition to interviews, we collected background information from messages exchanged by participants via social networks, leaflets and posters distributed by participants, newspapers, and polls conducted by sociological agencies. Though this article does not reflect all of this material, collecting it helped to formulate our hypotheses and enhance validity and reliability of results.

\section{Moral Shocks and Mobilization}

\section{Social and Political Contexts of Euromaidan}

The presidency of Yanukovych, who was legitimately elected in 2010, was marked with numerous contention-prone events. Altering the Constitution in order to enhance presidential powers (September 2010), introducing highly contestable tax changes for small businesses (autumn 2010), jailing opposition leader Tymoshenko (August 2011), and changing the government composition to favor his closest counterparts (January 2013) compose, but do not exhaust, the long list of political and economic grievances. Still, none of these frustrations produced a largescale protest: the protests that occurred were only limited in scope and local, incomparable to the Orange Revolution of 2004. During the Yanukovych's rule "protests rarely gathered at least some thousands of participants, and [the] overwhelming majority of Ukraine's citizens were not involved in protest activity."32 According to a common idea, expressed by the media and expert community, Ukrainians had grown so disappointed with the unsatisfactory results of the Orange Revolution that large-scale, antigovernment collective actions were impossible.

The political opposition's inability to mobilize citizens was another important factor. Its limited influence on political life increased after the manipulated elections system gave Yanukovych an opportunity to control the parliament in late 2012. Moreover, Yanukovych's adoption of the rhetoric and practices of European integration, took a key set of ideas from the opposition, limiting them to populist appeals and excessive concentration on Tymoshenko's case. Yanukovych's perceived resolution on the European integration path and the slow adoption of EU-like legislation brought a kind of consensus to Ukrainian society. Many seemed eager to forgive Yanukovych his excesses in exchange for an eventually successful European integration. The months before the scheduled signing of the Association Agreement were characterized a "Golden Age of Yanukovych era,"33 which came to a very abrupt end.

On 21 November, the government announced the postponing of the Association Agreement signing. That evening, a few dozen people headed towards the Independence Square in Kyiv, protesting against this U-turn. In the following days, the number of protesters grew and a few universities declared a strike. The repertoire of this contention copied the successful repertoire

Volodymyr Ishchenko, ed., Protesty, peremohy i represiiv Ukraini: resultaty monitorynhu 2011 [Protests, Victories, and Repressions: Monitoring Results of 2011] (Kyiv: Tsentr doslidzhennia suspilstva, 2012), 71. 
of 2004: the most active demonstrators left their desks, occupied the Independence Square, holding the ground days and nights, while others joined them after labor hours.

On the night of November 30, riot police known in Ukraine as Berkut, attacked the encampment at the Independence Square and brutally beat the people, predominantly students, there. This outraged many citizens. On the first Sunday after the Berkut assault (1 December), an immense mass rally, uniting hundreds of thousands of participants, took place in Kyiv. Some of the participants occupied the city council building. Some, at this stage labeled as "provocateurs," tried to attack police cordons with grinder, chains and stones. More and more protesters arrived from the regions, enlarging the encampment at the Independence Square. After the next Sunday rally of 8 December, protesters, anticipating a new Berkut assault, started building barricades around the camp and organized self-defense units. The Berkut tried to remove barricades on the night of 11 December but drew back. Although the demonstrators put a new claim — to punish those who had planned and realized the brutality of 3 o November - the regime preferred to wait until the people's fury evaporated. Despite all the calculations, the protest persisted.

Finally, the hard-liners within the ruling élites made a faux pas. On 16 January 2014, the Parliament passed harsh anti-protest acts through tremendous procedural violations, after which, a significant part of the protesters, persuaded of the futility of negotiations, adopted violent tactics. Hereafter, we limit our analysis to emotional content of the non-violent phase of the protest.

\section{Two Moral Shocks}

Given the underdevelopment of political parties' and social movements' networks in Ukraine, we argue that the contentious politics in November-December 2013 was enabled by emotions. Sociological data illustrates the shortcomings of the network paradigm in Euromaidan case: $92 \%$ of mass rallies participants did not belong to any political party or SMO. Moreover, describing the reasons of their mobilization, people referred to Yanukovych's refusal to sign the Association Agreement (53.5\%), the cruel beating of demonstrators on November 30 ( $70 \%)$, and their general discontent, manifested in a belief in the need to change those in power $(39 \%)$. Only $5^{-7} \%$ of people came to the Square because of the call of the opposition. ${ }^{34}$ Our empirical data corroborates the pattern: an absolute majority cited the refusal to sign the Association Agreement, the Berkut's brutality or both events as the reason for their protest, only 2 persons referred to peer-pressure or a friend's invitation. This does not preclude the presence of social networks where ideas and resources were exchanged; rather, participation in these networks was insufficient for mobilization.

We distinguish the first (refusal-motivated) and the second (brutality-motivated) waves of mobilization. In this section, we argue that although participants in both waves experienced vivid emotions, these emotions differed significantly in their content. By examining and comparing two emotional contents we intend to prove that (1) both the refusal to sign the Association

34 "Maidan-2013: Khto stoit, chomu i za shcho?" ["Maidan-2013: Who is Standing, Why, and for What?"]

The Ilko Kucheriv Democratic Initiatives Foundation, accessed March 19, 2014, http://www.dif.org.ua/ ua/polls/2013-year/mogjorjghoeoj.htm. 
Agreement and the Berkut's brutality caused moral shocks responsible for mobilization; (2) these shocks varied in their scale and scope; (3) and those differences were contextually dependent.

According to their responses, the first-wavers were the individuals who found the decision of the president to be arbitrary; they felt indignation, disappointment, and resentment; they believed that they were betrayed and demanded their opinion to be respected. Most of all, people were outraged by the suddenness of the reversal in public policy. The pro-European policy was planned and implemented over years but reversed in a week. The reaction of disbelief should be interpreted as a moral shock: there was an unexpected event that disturbed people emotionally and disposed them towards contentious politics. Initially, the response was neither planned nor well-coordinated: some outraged individuals responded to a journalist's spontaneous call to demonstrate distributed via Facebook. Later, the political opposition realized the opportunity and managed to organize a mass rally. Still, a driving force of this manifestation was the collective emotional élan of discontent over an "abduction of Europe," as it was later cleverly characterized.

The second group of demonstrators was mobilized a week later by a frequent source of moral shock - police brutality. ${ }^{35}$ The second-wavers were individuals stunned and enraged by the Berkut's actions. People could not believe this had happened. Then, facing the evidence, they experienced anger, fury, and hate. Their responses were overtly emotional. An old man explained with overwhelming bitterness: "One cannot beat livestock the way the Berkut have beaten up human beings. It is never to be excused and it brought us here." ${ }^{36}$ Other respondents were even more fulminating: "God, they [the Berkut] have not simply forced the people out, they openly beat the children! When I saw it on the TV, my whole soul started shaking. I felt ire, inexpressible wrath! I had to come, I felt I had to, otherwise they will beat us up at every turn."37

The Berkut's brutality provoked emotional reactions much stronger in scale and scope than the refusal to sign the Association Agreement. Increases in scale meant that people began to interpret the situation more emotionally and experienced it more intensely. Some, predominantly women, confessed they wept bitterly as if they, themselves, had been bodily harmed by the Berkut; others were outraged by the lawlessness of the state and law enforcement agencies. They experienced disgust at the government and the president and even expressed the desire to get rid of both immediately. Thus, emotional content of the second wave evolved significantly.

The emotional content evolved into dramatic accounts, such as unverified reports about a young girl killed by the Berkut on 30 November, the government bringing armored personnel carriers and tanks closer to Kyiv, Russian Special Forces landing in Ukraine, and speculation about an imminent storming of the encampment or the declaration of a state of emergency. While the greater part of such information proved to be false, its circulation revealed the high level of emotional tension and the shared conviction that the regime was acting brutally and

35 David Hess and Brian Martin, "Repression, Backfire, and the Theory of Transformative Events,"

Mobilization 11.2 (2006): 249-67.

36 Interview $N^{\circ}{ }_{12}$, December 8, 2013.

37 Interview $N^{\circ}$ 2, December 8, 2013. 
could act at anytime. It explains the sense of insecurity experienced by virtually all of the respondents, a sense that was "especially acute in nighttime." ${ }^{38}$ This shared sense of insecurity led to the demonstrators erecting barricades and organizing special patrol units to guard these barricades after dark.

The growth in the scope of emotional reactions socially diffused responses to the events and eventually diffused participation in the protests. This social diffusion had two forms: individual and sector. Individual social diffusion means that individuals who had never considered even a slightest possibility of contentious actions entered the protest movement after experiencing strong emotional reactions. One participant's response provides a telling example of the mechanism: "Frankly, I do not care if we should be closer to Russia or to the EU. The politics, I do not understand it much. But it hurts that children were beaten up. Before, I had no intention to come here, now I have come and brought 9 more people with my minivan. I really wanted to come, and I was driven by unnatural anger, I dreamed about tearing into pieces those, who had given the order."39 Another person explains: "Generally I am not interested in politics [...] but these days I went in the streets in order to protect our children and our future."40 These examples prove that emotional reactions, expressed either in the form of pure compassion for the innocent or as metaphorical leveling ("those beaten children are like mine"), reflect strong empathic bounds that converted bystanders into demonstrators. This mechanism of emotional mobilization is typical of a moral shock.

Sector social diffusion means that new segments of society were mobilized. Sociological studies of a mass rally on 8 December 2013 in Kyiv's city center reported over 500,000 participants representing different social strata and occupations. There were specialists (39.5\%), students $(13.2 \%)$, pensioners $(9.4 \%)$, businesspersons $(9.3 \%)$, managers $(8 \%)$, and workers $(6.7 \%) .{ }^{41}$ Such a mixed social structure differed from that of the first-wave (who were predominantly students and middle-class members) and showed that the sector diffusion, discussed by Tarrow, ${ }^{42}$ depends, among other, on emotional components.

Comparing the emotional content of both moral shocks, we found that emotional reactions to the Berkut's brutality were more primitive. First-wavers experienced highly intellectual reactions like offence, the indignation of citizens ignored by their government, or insult provoked by the lies of politicians. They were upset by the abruptly alternated "strategy of development of the country and the visions of its future." ${ }^{43}$ On the other hand, second-wavers were animated by more visceral feelings of disgust, anger, wrath, and fury. Although the sentiments of the first-

Interview $\mathrm{No}_{4}$, December 4, 2013.

Interview $N^{\circ} 1$, December 4, 2013.

Interview No 14, December 8, 2013.

"Maidan-Mitynh i Maidan-Tabir: Skhozhe i vidminne," ["Maidan as a Mass-Rally and Maidan as a

Camp: Similarities and Distinctions,"] The Ilko Kucheriv Democratic Initiatives Foundation, accessed March 19, 2014, http://www.dif.org.ua/ua/polls/2013-year/vjweojgvowerjoujgo.htm.

Sidney G. Tarrow, "Cycles of Collective Action: Between Moments of Madness and the Repertoire of Contention," Social Science History 17.2 (1993): 284-86. 
wavers were considerably closer to "moral emotions," 44 our argumentation is concurrent to that of Jasper. Being more primitive, the reflex-emotions were more effective as mobilizational stimuli, appealing not to people's convictions but to their empathy.

It is significant that many second-wavers were not able to precisely define their emotions and answered by describing their feelings. Still, they were confident while explaining the reasons they felt that way. It means that though emotionally disturbed, these participants were perfectly certain about the source of the disturbance. We argue that the combination of violent semi-conscientious emotions and clear understanding of the stimuli of these emotions is a mechanism of mobilization through a moral shock.

\section{Emotional Path Dependence}

If moral shock was crucial for the mobilization and diffusion of contention, why did only some individuals experience it? Why did not every Ukrainian citizen demonstrate his or her discontent? We argue that each event prone to provoke a moral shock resonates with an individual's political preferences, moral principles, social milieu values, and temperamental or psychological characteristics. Those elements compose a structure transmitting information about current events. As this structure filters information, individuals interpret it and react to it. We define the impact of this process as emotional path dependence.

Why did first-wavers experience moral shock, while the majority of their compatriots remained passive? Describing their emotions, first-wavers demonstrated a firm belief that adopting European norms and democratic values should change Ukraine for better. One participant stated: "I strongly support the event, which cherishes my hope that Ukraine will become a democratic state that respects human rights." ${ }^{45}$ Others were upset with the government's lack of transparency and accountability or with its arbitrary behavior. These negatively resonated with the commitment to democratic values of the to-be-participants and laid the foundation of the emotional path dependence. Such a commitment explains why firstwaivers mostly represented a relatively small social sector of enthusiastic students or middleclass members. After all, democratic values are poorly implanted in large societal groups in Ukraine.

The moral shock caused by the Berkut's brutality was much more resonant. Describing their emotions, respondents spoke about their astonishment. One of them, highlighting the perceived abnormality of the Berkut's brutality, stated: "they acted as if possessed by an evil spirit."46 A plausible explanation of this bewilderment resides in Ukraine's historical experience: Ukrainians have rarely experienced brutal clashes with police, and, assuming that the police would not be brutal this time, people were prepared to respond with indifference. Yet, when they saw what had happened, their astonishment rapidly transformed into outrage. Arguably, in societies with a long and continuous tradition of governmental repression, police brutality has little resonance: it is less likely to provoke a moral shock when compared to societies

44 Jasper, "Motivation and Emotion," 161.

45 Interview No 30 , December 11, 2013.

46 Interview $N^{\circ}{ }_{13}$, December 8, 2013. 
without such experience. This suggests that the nature of moral shock is historically and culturally embedded.

Moreover, due to the Berkut's brutality, the image of "abduction of Europe" was substituted with a more bleak "Slaughter of the Innocents." Many respondents gave a strikingly similar explanation of the motive of their participation: they referred to the fact that "the children were beat up," even though most of the victims of the 3 o November beatings were adults. Moreover, the answer was articulated not only by elderly people, but also by respondents in their twenties those who actually belonged in the same "child-age" category. The replication of the image and wording provoked more empathy and moved more people into protest movement. A senior lady told us: "Despite low wages I was paid, despite lie and humiliation I lived in, I accepted the situation. But I cannot tolerate the fact that they had acted so cruelly towards our dear youth." ${ }^{47}$ Another respondent uttered: "Those bastards, they are beating up our children! Most of us felt: something must be done in our country, but everyone, including myself, just waited. Well, here it is: they rounded up the students and that made me go in the street." 48 The shock from the Berkut's brutality overlapped with the critical reception of the refusal to sign the Association Agreement, which made many respondents define both events as central for their mobilization: "I was not really affected by the question of European integration. Yes, I came, spent some time on Independence Square and went away. But then the students were beaten, and later there was that bloody battle at Bankova street. During both events plenty of people suffered, and I faced the cynical and violent nature of the regime, which left me no choice but to protest."49

Anger, fury, rage, and indignation were the most common emotions, but even experienced and described as sudden outbursts, they were not spontaneous. We found that at the bedrock of vivid emotional reaction was a critical reception of the Yanukovych regime. Many respondents willingly emphasized that they had been active during the Orange Revolution, and that since that time they permanently experienced negative emotions towards Yanukovych and his cronies. The people considered the regime ineffective, politically closed, and fraudulent. They disapproved of the regime before, but their frail emotions contributed insignificantly to a fullscale mobilization. The moral shocks resonated with their negative attitude to the political regime, and, with that attitude now amplified, mobilized them.

The correlation between moral shock and preexisting experience was also observed in other case studies, e.g., the animal-rights ${ }^{50}$ and the U.S. Central America Peace Movement ${ }^{51}$ recruitments. In the Ukrainian case, the claim that moral shock is emotionally path dependent is confirmed not only by positive mobilization cases, but also by negative ones. People who openly supported the regime experienced no outrage due to the police brutality and approved it as being lawful and necessary.52 The moral shock caused by police brutality is thus not a universal moral reaction; on the contrary, it is a component of emotional path dependence.

\footnotetext{
$47 \quad$ Interview $\mathrm{N}^{\circ} 38$, December $13,2013$.

48 Interview No 5 , December 4, 2013.

49 Interview No 41, December 13, 2013.

$50 \quad$ Jasper and Poulsen, "Recruiting Strangers and Friends," 503-05.

$51 \quad$ Nepstad and Smith, "The Social Structure," 174.

$5^{2}$ Maksym Yakovlev, "Maidan i antimaidan v sotsialnykh setiakh: Kharakteristiki interpretatsionnykh ramok," ["Maidan and Antimaidan in Social Networks: Some Features of Interpretational Frames,"]
} 
Moral shocks are composite: negative emotions were built on some knowledge about Yanukovych regime and they were amplified by new information about regime's actions. This is a part of a "knowledge $\rightarrow$ emotion" mechanism. Simultaneously, emotions shape the cognitive functions: people mobilized by the Berkut's brutality interpreted negatively new information about regime policy. For instance, despite the sad state of Ukrainian economy, they blamed Yanukovych for visiting China with an economic agenda (17 December) and obtaining a loan from Russia. Thus, their cognitive horizons were framed by their emotional state, which is a part of "emotion $\rightarrow$ knowledge" mechanism. We argue that both mechanisms are prerequisite for a moral shock: emotions reinforce negative cognitive interpretations, while information perceived in a particular way reinforces emotional disturbance.

\section{Collective Identity and "We"-widening}

Moral shock as a vivid cognitive-emotional reaction contributes considerably to a spontaneous mobilization. However, being transient, it is unable to sustain collective action. This function is realized through emotional exchanges resulting in creating group identities. In this section, we survey the emotional part of creating an imagined community of protesters through emotional exchanges with (1) the companions, (2) the antagonists, represented by the government and the police forces, and (3) the observers, represented by the passive bystanders. We will show that those emotional exchanges supplement the cognitive and emotional components with the third perquisite of durable mobilization through moral shock-morality.

\section{The Brotherhood of the Virtuous: Emotions towards Companions}

Because Euromaidan participants represented different regions, occupations, and cultural backgrounds, we identify the protest collective identity as detached, following Tilly's distinction between embedded and detached identities. ${ }^{53}$ We argue that, absent in routine social interaction, the detached collective identity requires a remarkable emotional input from all the participants. The emotionally charged environment within the Euromaidan confirms our hypothesis.

Unsurprisingly, feelings towards companions were extremely positive, be it admiration and respect, 54 "warmth" 55 or "love" 56 towards the protest community. Experiencing powerful positive emotions, some individuals acquired personal confidence: they regained their "faith

Forum noveishei vostochnoevropeiskoi istorii i kultury 10.2 (2013): 74-83.

53 Charles Tilly, Contention and Democracy in Europe, 1650-2000

(New York: Cambridge University Press, 2004), 59.

54 Interview $N^{\circ}$ 2, December 8, 2013; Interview № 42, December 16, 2013;

Interview $\mathrm{No}^{\circ}$ o, December 12, 2013.

55 Interview $N^{\circ}$ 26, December 11, 2013; Interview $N^{\circ}$ 28, December 11, 2013;

Interview $\mathrm{N}^{\circ} 5^{2}$, December 20, 2013.

$56 \quad$ Interview $N^{\circ}{ }_{17}$, December 10, 2013; Interview No 26, December 11, 2013;

Interview No 42, December 16, 2013; Interview № 48, December 2O, 2013. 
in the future"57 and belief in their own "ability to make something joyful and life-asserting." 58 Participants linked their positive emotions to their companions standing by their side, being overwhelmed with massive feeling of gratitude, which redoubled their own desire to help. A young man put this explicitly: "I feel that many people are much better than me and this makes me to do everything I can to help those people."59

Intense positive emotions contributed significantly to destroying social boundaries and bridging social space. A woman in an expensive coat, surrounded by dirty-looking men, stated that she had not seen anyone who would have irritated her, ${ }^{60}$ which would be uncommon in other cases of social interaction. Positive emotions towards unknown, often dissimilar persons, significantly contributed to each individual's participation. The desire to feel unity with others brought people to the Independence Square repeatedly, which was directly stated by an older woman: "I like being here so much that I do not want to return home."61

As a result, feelings of sympathy, solidarity and unity dominated in our sample set. People felt "being among their own nation"62 and believed that the participants were "united not only physically, but mentally." ${ }^{3}$ The intense feeling of unity evolved to a feeling of true kinship, most often described in terms of "brotherhood." Lasting positive emotions towards the brothersparticipants contributed to delight in collective action: "I have never had such a stormy emotional experience - here everything is heated up by the atmosphere. People started to reach out for one another, and this makes me happy." 64

Contributing to the creation of collective identity, emotions were intersected with cognitive factors. People felt happiness because they believed that Euromaidan proved their political convictions to be true. Many respondents said that collective action proved the prevalence of patriotism among Ukrainians, trying to conceptualize what was happening in the terms of the nation-building. For instance, an 18-year-old girl declared herself to be "seized by joy, because we have proven, that we are the Ukrainian nation, we are united, the East and the West." ${ }^{65}$ Another respondent explained: "I am proud of our nation. I feel pity for those who are cold here, but we all together defend the most precious what we have - our freedom, our state, our future."66 Many respondents also considered the Euromaidan a cradle of civic society; an example of unprecedented civic self-organization that would one day become the foundation for rebuilding the corrupted state from the scratches. People expressed pride for such an unexpected civic awakening and rationally grounded their desire to support it.

Interview No 55 , December 21, 2013.

58 Interview No 22, December 10, 2013.

59 Interview $\mathrm{N}^{\circ} 36$, December 12, 2013.

6o Interview № 10, December 8, 2013.

61 Interview No 38 , December 13, 2013.

62 Interview No 27, December 11, 2013.

63 Interview No 37, December 13, 2013.

64 Interview $N^{\circ}$ 6, December 4, 2013.

65 Interview $N^{\circ} 7$, December 4, 2013.

66 Interview $N^{\circ} 5^{\circ}$, December 20, 2013. 
Given the emotionally and cognitively recognized importance of the Euromaidan, people eulogized the collective action as well as its participants:

I am proud of my people, of their ability to self-organize, to assert their own righteousness. The entire world is watching us today and apprentices this with us. Similar actions will take place all around the world, and that is why they, in Russia and Belarus, are so afraid of us. I feel that history is being made here. Every evening on the Independence Square I feel that everyone who comes here tears down the mask of tiredness, contempt, disappointment, paralysis of the will - and revives his or her mind. ${ }^{67}$

Such pompous self-laudations are extreme manifestations of the collective identity, constructed upon the confidence in the righteousness of the cause. The people in Independence Square had no doubt that they were acting according to pure moral requirements. Positive emotions experienced towards companions were a form of appreciation of the common case. Admiration, respect, love, solidarity, and gratitude destroyed the social boundaries between the participants, simultaneously erecting a new boundary between "us" and "them." Moreover, considering the collective action to be the purest stockpile of civic virtues, demonstrators started viewing protest participation as a moral obligation of every citizen.

Attributing morality to their actions, participants stepped forward in sustaining contentious action. A moral shock is an individual reaction to some repulsive event. Neither its emotional nor its cognitive component fulfill the requirement of universality: both are too immersed in a private universe of beliefs and values. Moreover, emotions are often treated as "irrational"; thus, people find it both difficult and useless to ground their claims by emotions. But resorting to morality makes any claims virtually universal and perfectly legitimate. Besides, it produces a particular emotional exchange with the broader public: those who ignore or impede it are described as immoral persons. The attitude and sentiments towards the antagonist are revealing in this respect.

\section{Emotions towards the Antagonist: Constructing the Enemy, Wiping out the Ambiguity}

Two moral shocks produced two types of antagonists: the government (including the president) and the police. The nature of the first moral shock made the contentious politics anti-governmental ab initio. Additionally, the majority of second-wavers blamed and rejected the "criminal regime that gave orders to beat children."68 Some respondents simply stated that government's "time to quit has come" 69 or "we need to take rubbish out of the house."70 Other respondents exposed anger, distrust, and indignation. In both cases, the government was

\footnotetext{
67 Interview No 33 , December 12, 2013.

68 Interview $\mathrm{No}_{3}$, December 4, 2013.

69 Interview $N^{\circ} 4$, December 4, 2013.

$7 \mathrm{O}$ Interview $\mathrm{No}_{5}$, December 4, 2013.
} 
considered an illegitimate political actor, "a mob of bandits"71 making "the state to live according to the rules of thieves." 72

The personality of the president stirred up an even less dissimulated feeling of discontent. For the participants he was the avatar of everything bad that was happening in Ukraine. The range of negative reactions was very wide: people spoke of contempt, disgust, disappointment, hate, shame, disdain, distrust, disrespect. Respondents were quite creative in inventing aggressive and degrading characteristics: "corrupt cattle,"73 "paltry fellow,"74 "backboneless, brainless puppet,"75 "monster of cruelty," 76 "thief that cannot connect two words together"77 or "a piece of shit that considers itself to be a bullet." 78 The common idea was that the current president was so corrupt and immoral that he should quit his post in any way possible: some respondents openly wished his death. Thus, the emotional and moral boundary between "us" (good and law-abiding citizens) and "them" (the gang of criminals encroaching political power) reinforced the collective identity of protest participants.

This boundary, however, tended to be more transparent when the respondents described their feelings toward law-enforcement agencies. On the one hand, the Berkut's brutality was the main reason of the second moral shock and, consequently, it provoked negative, strong, and simple feelings: rage, fury, and hate. Some treated the Berkut's brutality as an act incompatible with officer's honor or even as the personal offence: an old man claimed that "they have trampled on my feelings." ${ }^{99}$ Moreover, the imagery of the "Slaughter of Innocents" complicated the emotional content, branding the Berkut as an actor who violated the basic societal rule and became morally unacceptable. For this reason, respondents also experienced complicated moral emotions of indignation, contempt, disgust, offence, and disappointment. Associating the Berkut with absolute evil also involved dehumanization: respondents were constantly underlining the inadequateness of the troops, i.e. bestiality, inhuman cruelty, "ungrounded desire of aggression lurking in their red eyes." ${ }^{\text {80 }}$ Such an emotional content provoked willingness to eradicate the unit - either institutionally, as "a criminal organization that has to be disbanded"81 or even physically: one respondent urged that "we need to castrate them, because they must not procreate" ${ }^{\text {"2 }}$ and another called for "burn[ing] the crap." 83

\footnotetext{
$71 \quad$ Interview $N^{\circ} 30$, December 11, 2013.

72 Interview No 19, December 10, 2013.

73 Interview № 2, December 4, 2013.

74 Interview No 6, December 4, 2013.

75 Interview $N^{\circ} 3$, December 11, 2013.

76 Interview No 38 , December 13, 2013.

77 Interview No 44, December 19, 2013.

78 Interview No 22, December 10, 2013.

79 Interview No 20, December 10, 2013.

8o Interview № 8, December 6, 2013.

81 Interview No 54, December 21, 2013.

82 Interview No 57 , December 24, 2013.

83 Interview $\mathrm{No}_{5}$, December 4, 2013.
} 
On the other hand, a significant number of respondents confessed their emotional ambiguity towards the law-enforcement agencies. Though blaming the Berkut for its cruelty, they placed responsibility for the brutality on the regime, speaking of police officers as "also defenseless against our state, represented by the president." ${ }^{84}$ Consequently, people explained the actions of the Berkut with the obligation to obey the orders - they felt some pity, understanding that the police were acting under pressure and risked losing their job in case of disobedience, treating them as the hostages of their profession.

An even more pronounced pattern of ambiguity was observed in emotional reactions to the regular police. Most reactions were negative, consisting of disgust, contempt, disrespect, caution, and shame. Still, the hate was not as violent as in the case of the Berkut. Many respondents shared the view that not all the people wearing uniforms were villains. They treated the police with compassion and pity, trying to find some commonality between them and the protesters: "they are used as cannon fodder," 85 "they stand here against their own free will and protect things they do not like themselves," 86 "they obey to the orders of the government, but probably they are the same people as we are." 87

This ambiguity reached its apogee when the "beaten children" imagery found its unexpected reflection in the relation to the 17- to 19-year-old conscripts of the Interior Troops serving as the first row of a human shield posted around governmental buildings. The image of unarmed, defenseless "children" of the Interior Troops suffering through several hours of angry attacks with a grinder, chains and stones during the storming of the Presidential Administration on 1 December (while armed Berkut stayed in the rear), further blurred the frontier between "us" and "them." And, for a short period, this even called into question the sense of moral righteousness experienced by our informants. The radicals beating these "children" were initially called "provocateurs," although the final responsibility for covering with "children" was placed on the government. One respondent fulminated: "They made those children keep the defense in the cold, stand in the frost! God, that's insane! That's an atrocity: you cannot call those who put the guys to stand in the frost humans!"88

We believe that ambivalent emotional reaction towards law-enforcement agencies reflects the dynamics of contentious politics. Protest participants considered themselves as people acting according to the law: they went into the streets because the government has ignored the wishes of citizens and used force against a non-violent mass rally. It was the government and the president themselves who acted unlawfully and who, according to widespread opinion, represented criminal elements. Therefore, people initially considered law-enforcement agencies as a potential ally that could help during the confrontation with non-law-abiding actors. Some respondents expressed the hope that "at least one detachment commander will order his men to defend the people with their shields," 89 because police "should stand by the side of

\footnotetext{
84 Interview $\mathrm{N}^{\circ} 37$, December 13, 2013.

85 Interview No 5 , December 4, 2013.

86 Interview № 8, December 6, 2013.

$87 \quad$ Interview $\mathrm{N}^{\circ} 5^{\circ}$, December 20, 2013.

88 Interview № 38 , December 13, 2013.

89 Interview No 37 , December 13, 2013.
} 
the ordinary people, not on the side of the convict."90 The sentiments of pity and compassion towards the police communicated the willingness of our informants to accept the antagonist as potential "us." For this reason, the boundary cutting "the police" and "the people" remained transparent for some time. In this first phase, the practice of feeding the police or bringing them hot beverages was quite widespread.

Still, as with the course of contentious politics law-enforcement agencies continued to be loyal to the regime, and as the hopes of police allying with the people vanished, the differences between good and bad police, between the police as a whole and the government, blurred. As the conflict went on and the government became more and more delegitimized in the eyes of protesters, the emotions towards both became more and more coherent: the police were simple defenders of "the Gang" against whom the use of the stones and Molotov cocktails became fully acceptable.

\section{Bystanders between Rejection and Tutelage}

The silent majority of bystanders occupied much of the imagination of our respondents, who not only reported their emotional relations, but also tried to classify the bystanders and invent some mechanisms of involving them in the protest. Though some respondents professed respect of a different point of view, generally the relation to the bystanders was far less detached. Perceiving Euromaidan as the fight between the moral and the unmoral, participants were eager to fight for souls of those who did not join their ranks.

Numerous respondents expressed their hope that there were many supporters who could not join the protests because of problems at the workplace, their desire not to close their business, or family problems. These were considered as a rear, helping the protest in other ways, e.g., by sending money, or as a reserve that would surely join later. Sometimes those bystanders who expressed verbal support but refrained from active participation were considered cowards (as one man put it metaphorically: "I would not share a foxhole with such people"91) or as infused with "passivity and philistinism." ${ }^{92}$ Nevertheless, the hope to widen the protest base persisted.

At the same time, a conscious passive or spectator position met extreme disapproval; many respondents signalized surprise, incomprehension and offence about it. Given that participants considered themselves righteous citizens protecting their rights and the fact that they often thought about contentious actions as a moral obligation, it was unbelievable and inadmissible to them that others could ignore the Euromaidan. Respondents confessed "feeling rage toward those who are indifferent to us"93 and "being irritated by people who live in shit and cherish this shit." 94

We argue that negative emotions experienced towards bystanders were a consequence of collective identity formation that erected a boundary between the "virtuous us" and the

\footnotetext{
9o Interview $N^{\circ}$ 9, December 6, 2013.

91 Interview $\mathrm{No}_{4}$, December 4, 2013.

92 Interview $N^{\circ}$ 31, December 11, 2013.

93 Interview № 6, December 4, 2013.

94 Interview No 25, December 10, 2013.
} 
"wicked them." This was the same emotional mechanism that contrasted protest participants and governmental élites and helped to sustain emotional tonus of contentious actors. Bystanders were often blamed for moral inferiority that was reflected in many degrading personal characterizations like "spineless, lacking in character and not deserving to live in a better country,"95 "amoebae who do not want to influence their fate,"96 "a category with the slave world-view"97 or even "an empty place in society."98

On the other hand, unlike élites, the bystanders were not rejected completely. There was a hope that one day they might join the contentious collective action. Therefore, the identity boundary did not cut off bystanders; it just highlighted their "otherness." In this respect, the attitude towards them was similar to those towards the police, but with a significant difference: the police were considered a powerful and autonomous actor that could become an ally. Thus, protesters felt a mix of fear and respect, distrust and expectation. Bystanders, on the other hand, were viewed as dependent and weak persons, unable to act unassisted and incapable of clear judgments, and as minors assisting an important event without fully realizing its significance.

This explains why bystanders were constantly blamed for not knowing and not understanding the history, the seriousness of the situation, and the consequences of the events. They were also depicted as individuals without will and readiness to struggle, as victims of the false information circulating in the media. As one of the respondents put it, "I think that part of these people has just lost hope that it is still possible to change something in our country. And another part - probably due to lack of information - has a distorted image of everything that is happening. But both parts are united in desiring the dismissal of the government." 99 This idea that people do not understand because they are misinformed added an important emotional component, i.e., a desire to proselytize and enlighten. According to a common opinion, "if we want changes, we should work with people - teach them, explain, enhance the level of culture, morals, and inculcate the correct values."100

Metaphorically, the protestors perceived themselves as adult citizens who approached the infantile population with a readiness to help and to guide. This perception clarifies the correlation between emotional, cognitive, and moral components of contentious politics. A collective identity is necessary for a durable collective action. It is built upon shared positive emotions and common cognitive perspectives, bonded by universalistic morality, which produces a selfimage of "righteous Us." Given the centrality of the moral component, contentious actors excuse emotional and cognitive failings more easily than moral ones: bystanders and the police may be unaware of political situation (cognitive failure) or too frightened to participate (emotional failure), yet still remain a potential ally. Once they turn to be corrupted or indifferent to communal future (moral failure), they step beyond the imaginary boundary of "Us."

\footnotetext{
95 Interview No 21, December 10, 2013.

96 Interview $\mathrm{N}^{\circ} 3$, December 4, 2013.

97 Interview $\mathrm{No}_{5}$, December 4, 2013.

98 Interview No 37, December 13, 2013.

99 Interview $N^{\circ} 5^{2}$, December 20, 2013.

100 Interview $N^{\circ} 56$, December 23, 2013.
} 


\section{Conclusions}

Ourintention is to enhance our understanding of the role of emotions in contentious mobilization and protest sustaining. Studying emotions in the first phase of Ukrainian Euromaidan protest, we found overwhelming support for emotion-centered approach to contentious politics.

First, the rapid mobilization of Ukrainian citizens in late 2013 was enabled by the overlapping of two successive moral shocks - the one provoked by the government's refusal to sign the Association Agreement and the second by police brutality. According to our interpretation, the emotional content of the second moral shock, being more primitive, contributed to broader social diffusion of discontent. We also suggest that different emotional reactions were determined by emotional path dependence - the impact of culture and values upon the interpretation of current political events. According to our data, people rarely experienced spontaneous negative emotions towards the regime; rather, those previously existing beliefs, attitudes, and loyalties were amplified by one or both moral shocks. Thus, moral shock is contextually dependent phenomenon.

Second, our findings confirm current trend in the scholarship, proving that emotions and cognition are intertwined. We provide additional arguments to that opinion, showing that a moral shock is a constellation of emotional reactions with cognitive work: it happens only if emotions reinforce negative interpretations of some social or political event, while information perceived in a particular way reinforces emotional disturbance.

Third, our data corroborates the hypothesis that emotions are important mechanisms of collective identity construction as a way to sustain the protest. We find that actors involved in contentious politics coalesce through enhanced positive emotions, creating the image of a unity. To put the boundaries between "collective Us" and the antagonist as well as bystanders, the self-image as a moral actor is crucial. The morality is instrumental, because resorting to morality makes contentious claims quasi-universal and legitimate. The perceived universality of contentious claims and the feeling of moral righteousness serve to recruit new allies by making the bystanders' position unacceptable. In other words, the dual emotional-cognitive nature of mobilization through moral shock needs a supplement of moral component in order to be stable and durable. The morality became central for contentious action. Emotional exchanges with antagonists and bystanders prove that contentious actors excuse emotional and cognitive failings more easily than moral ones.

\section{Bibliography}

Adams, Jacqueline. “The Bitter End: Emotions at a Movement's Conclusion." Sociological Inquiry 73.1 (2003): 84-113.

Aminzade, Ron, and Doug McAdam. "Emotions and Contentious Politics." In Silence and Voice in the Study of Contentious Politics, edited by Ron Aminzade et al., 14-50. Cambridge: Cambridge University Press, 2001.

Blumer, Herbert. "Collective Behavior." In Principles of Sociology, edited by Alfred McClung Lee, 65-121. New York: Barnes and Noble, 1969. 
Cohen, Jean. "Strategy or Identity: New Theoretical Paradigms and Contemporary Social Movements." Social Research 52.4 (1985): 663-716.

Collins, Randall. "Social Movements and the Focus of Emotional Attention." In Passionate Politics: Emotions and Social Movements, edited by Jeff Goodwin, James M. Jasper, and Francesca Polletta, 27-44. Chicago, Ill.: University of Chicago Press, 2001.

de Volo, Lorraine Bayard. "The Dynamics of Emotion and Activism: Grief, Gender, and Collective Identity in Revolutionary Nicaragua." Mobilization 11.4 (2006): 461-74.

Emirbayer, Mustafa and Goldberg, Chad A. "Pragmatism, Bourdieu, and Collective Emotions in Contentious Politics." Theory and Society 34 (2005): 469-518.

Eyerman, Ron. "How Social Movements Move: Emotions and Social Movements." In Emotions and Social Movements, edited by Helena Flam and Debra King, 41-56. Abingdon: Routledge, 2005 .

Ferree, Myra Marx and Miller, Frederick D. "Mobilization and Meaning: Toward an Integration of Social Psychological and Resource Mobilization Perspectives on Social Movements." Sociological Inquiry 55.1 (1985): $33^{8-51 .}$

Flam, Helena. "Emotional Man. Part 1: The Emotional Man and the Problem of Collective Action." International Sociology 5.1 (1990): 39-56.

Gamson, William A. The Strategy of Social Protest. Homewood, IL: Dorsey Press, 1975.

Gamson, William A. "Constructing Social Protest." In Social Movements and Culture, edited by Hank Johnston and Bert Klandermans, 85-106. Minneapolis: University of Minnesota Press, 1995.

Goodwin, Jeff, James M. Jasper, and Francesca Polletta. "The Return of the Repressed: The Fall and Rise of Emotions in Social Movement Theory." Mobilization 5.1 (2000): 65-83.

Goodwin, Jeff. "The Libidinal Constitution of a High-Risk Social Movement: Affectual Ties and Solidarity in the Huk Rebellion, 1946 to 1954." American Sociological Review 62.1 (1997): $53-69$.

Gould, Deborah. "Passionate Political Processes: Bringing Emotions Back into the Study of Social Movements." In Rethinking Social Movements, edited by Jeff Goodwin and James M. Jasper, 155-75. Lanham, MD: Rowman and Littlefield, 2003.

Gould, Robert V. "Multiple Networks and Mobilization in the Paris Commune." American Sociological Review 56.6 (1991): 716-29.

Hess, David and Martin, Brian. "Repression, Backfire, and the Theory of Transformative Events." Mobilization 11.2 (2006): 249-67.

Hoffer, Eric. The True Believer. New York: Frederic A. Praeger, 1962.

Ishchenko, Volodymyr. Protesty, peremohy i represii v Ukraini: resultaty monitorynhu 2011 [Protests, Victories, and Repressions: Monitoring Results of 2011]. Kyiv: Tsentr doslidzhennia suspilstva, 2012.

Jasper, James M. and Poulsen, Jane. "Recruiting Strangers and Friends: Moral Shocks and Social Networks in Animal Rights and Anti-Nuclear Protests." Social Problems 42.4 (1995): 493-512.

Jasper, James M. The Art of Moral Protest: Culture, Biography, and Creativity in Social Movements. Chicago: University of Chicago Press, 1997. 
Jasper, James M. "The Emotions of Protest: Affective and Reactive Emotions in and around Social Movements." Sociological Forum 13.3 (1998): 397-424.

Jasper, James M. "Motivation and Emotion." In Oxford Handbook of Contextual Political Analysis, edited by Robert Goodin and Charles Tilly, 157-72. New York: Oxford University Press, 2006. Jasper, James M. "Cultural Approaches in the Sociology of Social Movements." In Handbook of Social Movements across Disciplines, edited by Bert Klandermans and Conny Roggeband, 59-110. New York: Springer, 2007.

Jasper, James M. "Emotions and Social Movements: Twenty Years of Theory and Research." Annual Review of Sociology 37 (2011): 285-303.

Kemper, Theodore D. A Social Interactional Theory of Emotions. New York: Wiley, 1978.

Kemper, Theodore D. "A Structural Approach to Social Movement Emotions." In Passionate Politics: Emotions and Social Movements, edited by Jeff Goodwin, James M. Jasper, and Francesca Polletta, 58-73. Chicago, Ill.: University of Chicago Press, 2001.

Kim, Hyojoung. "Shame, Anger, and Love in Collective Action: Emotional Consequences of Suicide Protest in South Korea, 1991." Mobilization 7.2 (2002): 159-76.

Le Bon, Gustave. Psychologie des foules. Paris: Édition Félix Alcan, 1905.

Lofland, John. "Charting Degrees of Movement Culture: Tasks of the Cultural Cartographer." In Social Movements and Culture, edited by Hank Johnston and Bert Klandermans, 188-216. Minneapolis: University of Minnesota Press, 1995.

McAdam, Doug. "Culture and Social Movements." In New Social Movements: From Ideology to Identity, edited by Enrique Laraña, Hank Johnston and Joseph R. Gusfield, 36-57. Philadelphia: Temple University Press, 1994.

McAdam, Doug and Paulsen, Ronnelle. "Specifying the Relationship between Social Ties and Activism." American Journal of Sociology 99.3 (1993): 640-67.

McAdam, Doug, Sindey G. Tarrow, and Charles Tilly. Dynamics of Contention. Cambridge: Cambridge University Press, 2004.

McCarthy, John D. and Zald, Mayer N. "Resource Mobilization and Social Movements: A Partial Theory." American Journal of Sociology 82.6 (1977): 1212-41.

McCauley, Clark and Sophia Moskalenko. "Mechanisms of Political Radicalization: Pathways Toward Terrorism." Terrorism and Political Violence 20.3 (2008): 415-33.

Melucci, Alberto. "The Process of Collective Identity in Social Movements and Culture." In Social Movements and Culture, edited by Hank Johnston and Bert Klandermans, 41-64. Minneapolis: University of Minnesota Press, 1995.

Morris, Aldon. The Origins of the Civil Rights Movement. New York: Free Press, 1984.

Nepstad, Sharon Erickson and Smith, Christian S. "The Social Structure of Moral Outrage in Recruitment to the U. S. Central America Peace Movement." In Passionate Politics: Emotions and Social Movements, edited by Jeff Goodwin, James M. Jasper, and Francesca Polletta, 158-74. Chicago: University of Chicago Press, 2001.

Oberschall, Anthony. Social Conflict and Social Movements. Englewood Cliffs, NJ: Prentice Hall, 1973 .

Snow, David A. and McAdam, Doug. "Identity Work Processes in the Context of Social Movements: Clarifying the Identity/Movement Nexus.” In Self, Identity and Social Movements, edited by 
Sheldon Stryker, Timothy J. Owens, and Robert W. White, 41-67. Minneapolis: University of Minnesota Press, 2000.

Staggenborg, Suzanne. “The 'Meso' in Social Movement Research.” In Social Movements: Identity, Culture, and the State, edited by David S. Meyer, Nancy Whittier, and Belinda Robnett, 12440. New York: Oxford University Press, 2002.

Sushko, Oleksandr. "Vilniuskyi Rubikon: Kinets 'Zolotoho Viku' Yanukovycha." ["Rubicon at Vilnius: The End of Yanukovych's 'Golden Age.”'] Accessed February 10, 2014. http://blogs. korrespondent.net/celebrities/blog/sasha5/a12436o.

Tarrow, Sidney G. "Old Movements in New Cycles of Protest: The Career of an Italian Religious Community." International Social Movement Research 1 (1988): 281-304.

Tarrow, Sidney G. "Cycles of Collective Action: Between Moments of Madness and the Repertoire of Contention." Social Science History 17.2 (1993): 281-307.

Tarrow, Sidney G. Power in Movement. Cambridge: Cambridge University Press, 2011.

Tilly, Charles. Contention and Democracy in Europe, 1650-200o. New York: Cambridge University Press, 2004.

The Ilko Kucheriv Democratic Initiatives Foundation. "Maidan-2013: Khto stoit, chomu i za shcho?" ["Maidan-2013: Who is Standing, Why, and for What?"] Accessed March 19, 2014. http://www.dif.org.ua/ua/polls/2013-year/mogjorjghoeoj.htm.

The Ilko Kucheriv Democratic Initiatives Foundation. "Maidan-Mitynh i Maidan-Tabir: Skhozhe i vidminne." ["Maidan as a Mass-Rally and Maidan as a Camp:Similarities and Distinctions."] Accessed March 19, 2014. http://www.dif.org.ua/ua/polls/2013-year/vjweojgvowerjoujgo. htm.

Touraine, Alain. La Voix et le Regard. Paris: Éditions du Seuil, 1978.

Van Zomeren et al. "Put Your Money Where Your Mouth Is! Explaining Collective Action Tendencies through Group-based Anger and Group Efficacy." Journal of Personality and Social Psychology 87.5 (2004): 649-64.

Walsh, Edward J. "Resource Mobilization and Citizen Protest in Communities around Three Mile Island." Social Problems 29.1 (1981): 1-21.

Whittier, Nancy. "Meaning and Structure in Social Movements." In Social Movements: Identity, Culture, and the State, edited by David S. Meyer, Nancy Whittier, and Belinda Robnett, 289307. New York: Oxford University Press, 2002.

Wood, Elisabeth Jean. "The Emotional Benefits of Insurgency in El Salvador." In Passionate Politics: Emotions and Social Movements, edited by Jeff Goodwin, James M. Jasper, and Francesca Polletta, 267-81. Chicago, Ill.: University of Chicago Press, 2001.

Yang, Guobin. "Emotional Events and the Transformation of Collective Action." In Emotions and Social Movements, edited by Helena Flam and Debra King, 79-98. Abingdon: Routledge, 2005 .

Yakovlev, Maksym. "Maidan i antimaidan v sotsialnykh setiakh: Kharakteristiki interpretatsionnykh ramok." ["Maidan and Antimaidan in Social Networks: Some Features of Interpretational Frames."] Forum noveishei vostochnoevropeiskoi istorii i kultury 10.2 (2013): 74-83.

Zolberg, Aristide R. "Moments of Madness." Politics and Society 2 (1972): 183-207. 
Ivan Gomza, $\mathrm{PhD}$, is an Associate Professor of Political Science at the National University of KyivMohyla Academy. His scholarly interests include contentious politics with special focus on the strategies of contention within authoritarian regimes. His recent publications are: "The Elusive Proteus: A Study in Ideological Morphology of the Organization of Ukrainian Nationalists" (Journal of Communist and Post-Communist Studies, 2015, in English), "Contentious Politics and Repertoire of Contention in Ukraine: The Case of Euromaidan” (Mahisterium: Politychni studii, 2014, in English); "Catalytic Mobilization of Radical Ukrainian Nationalists in the Second Polish Republic: The Impact of Political Opportunity Structure" (Ukraina Moderna, 2013, in Ukrainian); "Multi-Sectoral Classification of Authoritarian Regimes" (Naukovi zapysky NaUKMA, 2014, in Ukrainian).

Nadiia Koval is a political analyst at the National Institute for Strategic Studies in Kyiv and pursues a $\mathrm{PhD}$ thesis devoted to comparative analysis of reconciliation politics between GreeceTurkey and Ukraine-Poland at the National Institute of Oriental Languages and Civilizations in Paris. Her research interests revolve around reconciliation politics both in its international and interstate dimensions, with a special emphasis on identity building and the uses of historical memory in the process. Her latest articles are: "The School History Textbook for the Balkans: From Pedagogical Innovation to Political Reality" (Ukraina Moderna, 2012, in Ukrainian); "L'Europe centrale dans la cartographie mentale des intellectuels ukrainiens d'aujourd'hui" (Anatoli, 2011, in French); "Balkan Identity in Cultural Diplomacy of the Hellenic Foundation for Culture in the Balkans" (Hileia: Naukovyi visnyk, 2010, in Ukrainian). 